\title{
Effective tax rate (ETR) measures: alternatives and their validity
}

Citation for published version (APA):

Janssen, J. B. P. E. C. (2000). Effective tax rate (ETR) measures: alternatives and their validity. METEOR, Maastricht University School of Business and Economics. METEOR Research Memorandum No. 048 https://doi.org/10.26481/umamet.2000048

Document status and date:

Published: 01/01/2000

DOI:

10.26481/umamet.2000048

Document Version:

Publisher's PDF, also known as Version of record

\section{Please check the document version of this publication:}

- A submitted manuscript is the version of the article upon submission and before peer-review. There can be important differences between the submitted version and the official published version of record.

People interested in the research are advised to contact the author for the final version of the publication, or visit the DOI to the publisher's website.

- The final author version and the galley proof are versions of the publication after peer review.

- The final published version features the final layout of the paper including the volume, issue and page numbers.

Link to publication

\footnotetext{
General rights rights.

- You may freely distribute the URL identifying the publication in the public portal. please follow below link for the End User Agreement:

www.umlib.nl/taverne-license

Take down policy

If you believe that this document breaches copyright please contact us at:

repository@maastrichtuniversity.nl

providing details and we will investigate your claim.
}

Copyright and moral rights for the publications made accessible in the public portal are retained by the authors and/or other copyright owners and it is a condition of accessing publications that users recognise and abide by the legal requirements associated with these

- Users may download and print one copy of any publication from the public portal for the purpose of private study or research.

- You may not further distribute the material or use it for any profit-making activity or commercial gain

If the publication is distributed under the terms of Article $25 \mathrm{fa}$ of the Dutch Copyright Act, indicated by the "Taverne" license above, 


\title{
Effective tax rate (ETR) measures: alternatives and their validity
}

\author{
Boudewijn Janssen*
}

MARC Working Paper MARC-WP/3/2000-10

*MARC and Accounting and Auditing Section, Universiteit Maastricht, PO Box 616, 6200 MD Maastricht, the Netherlands; email: JB.Janssen@berfin.unimaas.nl

The author wishes to thank Prof. dr. J.M.J. Blommaert, dr. L.H.H. Bollen and Prof. dr. W.F.J. Buijink for comments on an earlier version of this paper. 


\title{
Effective tax rate (ETR) measures: alternatives and their validity
}

\begin{abstract}
Corporate tax related empirical research often uses effective tax rates to investigate crosssectional differences in the tax attributes of companies. Effective tax rates are often defined as (current or total) tax expense over financial accounting income before taxes, where the (current or total) tax expense is an estimate of the actual taxes paid. This approximation of the actual tax payment by using tax expense is often used, as the actual tax payment and taxable income were or are proprietary information, thereby rendering it difficult if not impossible to use this information to calculate effective tax rates. Due to changes in financial accounting standards more information on the actual tax payment and taxable income is now generally available in US financial statements. This paper argues that the use of an effective tax rate measure utilizing tax expenses has some inherent dangers which are to a lesser extent the case in an effective tax rate using actual taxes paid. Two inherent dangers of a tax expense based ETR measure are the quality of the tax expense measure as an estimation of the actual taxes paid and timing differences between tax expense and actual taxes paid. The differences between tax expenses and actual taxes paid ETRs are researched in an empirical study as well as other proposed ETR measures. Results from this empirical study indicate that in certain situations it is more appropriate to use an effective tax rate measure based on actual taxes paid rather than on tax expenses.
\end{abstract}




\section{INTRODUCTION}

A large body of US research has focused on the corporate tax attributes of corporations. Two of the main issues addressed in this research relate to the level of taxation of companies and secondly to company attributes related to cross-sectional differences in the tax attributes (especially the corporate tax burden) of companies. Both issues are related to the equitability of the corporate income tax system and in doing so play a role in the political decision making process especially with regard to the extension of tax preferences to companies.

One particular issue in this line of research that is still ambiguous is the measurement of the tax attributes. Often these tax attributes are measured by the effective tax rate measure (ETR). The effective tax rate measure is defined as (current or total) tax expense over financial accounting income before taxes (Scholes and Wolfson, 1992). Where (current or total) tax expense is an estimate of the company's real tax burden taking into account permanent and temporary differences between financial accounting income and taxable income. An estimate inherently has flaws. The question researched in this paper is whether these flaws are significant and in doing so answers a question about the validity of the tax expense effective tax rate (ETR) measure. It also discusses alternative ETR measures and their validity.

This paper proceeds as follows. First, in chapter two previous research is discussed, while chapter three describes the alternatives available for ETR measurement. Chapter four describes the empirical setting for the research question, where chapter five describes the results of this empirical setting. Chapter six ends with the conclusion. 


\section{PREVIOUS RESEARCH}

\subsection{General}

To a large extent previous tax accounting research had focused on determining the relative level of average effective explicit taxes, hereafter referred to as effective tax rates (ETRs) and investigating inter-company and inter-industry differences in ETRs. Only a limited amount of studies has addressed the different possibilities available to measure ETRs. These studies are addressed below. But first the different lines of research are addressed to put this paper's research in perspective.

\subsection{ETR research}

A notable body of research on explicit taxes has focused along three research questions. Firstly, how to define ETRs and which ETR measure to use (e.g. Omer, et. al. (1991), Wilkie and Limberg (1993)). This line of research has indicated that alternative ETR measures can cause notable shifts in estimated ETRs, but has not yet provided a conclusive answer as to which ETR measure to use. The two other lines of research have often defined ETR as a tax expense measure (either in- or excluding deferred taxes) divided by a financial accounting income before tax measure, where the exact definition was dependent upon the research issue as well as the source of information used to provide estimates of tax and income (Omer, et. al. (1991)).

The second research question addressed in prior research is, what is the (cumulative) effect of tax preferences on the amount of taxes paid by companies? The amount of taxes paid by companies is proxied by measuring the ETR and comparing the ETR either to the statutory tax rate or cross-sectionally. This particular research question has often been combined with the third research question, which factors (like company characteristics) are associated with crosssectional differences in ETRs (e.g. Gupta and Newberry (1992 and 1997), Holland (1998), Porcano (1986), Stickney and McGee (1982), Wang (1991), Wilkie and Limberg (1990) and Zimmerman (1983)). 
Results of the second line of research confirm that there can be large differences between the statutory tax rates and the effective tax rates. In general the ETR tends to be below the statutory tax rate (e.g. Wang (1991)). Results regarding factors associated with cross-sectional differences

in ETRs are mixed, although there seem to be industry differences in ETR (e.g. Holland (1998)). Callihan (1994) provides a comprehensive overview of ETR research, which also discusses the ETR measures used in this research line.

\subsection{ETR measure research}

Although the second and third line of research have investigated cross-sectional differences in ETR, different definitions of ETR have been used. The general format for firm $\mathrm{i}$ in year $\mathrm{t}$ is (Callihan, 1994):

$$
\mathrm{ETR}_{\mathrm{ti}}=\mathrm{TE}_{\mathrm{ti}} / \mathrm{PTI}_{\mathrm{ti}}
$$

where: $\mathrm{TE}_{\mathrm{ti}}=$ financial accounting tax expense (in- or excluding deferred taxes; thus representing total or current taxes)

$\mathrm{PTI}_{\mathrm{ti}}=$ financial accounting income before taxes ('pre-tax income')

Two early analytical papers to look at the effective tax rate on capital income are Fullerton (1984) and Spooner (1986). Both papers use an economics point of view. Fullerton (1984) focuses on distinguishing between the various ETR definitions and categorizing them in four basic types with six subclasses. Distinguishing classes are average ETR versus marginal ETR, total ETR (including corporate, personal and property taxes) versus corporate ETR and ETRs versus effective tax wedges (Fullerton, 1984). Fullerton also comments on the differences between marginal and average effective tax rates but does not introduce any alternative ETR measure.

Spooner (1986) discusses the different methodologies for measuring average effective tax rates from financial statements and the problems associated with the various methodologies. Although the study elaborates on the second flaw in the methodology (see also section 3.3), it does not provide a solution to the mentioned shortcomings of ETRs.

One of the more recent papers to look at ETR definitions is Omer, Molloy and Ziebart (1991), using five different ETR measures based on previous research and investigating differences in 
rankings of companies using these ETR measures. Four of these ETR measures use the general format of (1), whereas one definition uses operating cash flow as denominator. The first four definitions differ with respect to the in- or exclusion of foreign tax expense, deferred taxes, change in investment tax credit, change in deferred tax liability, income from unconsolidated subsidiaries, income from extraordinary and discontinued operations, income from minority interests, relative change in deferred tax liability to statutory marginal tax rate and relative change in deferred tax expense to statutory marginal tax rate (Omer, Molloy and Ziebart, 1991). The descriptive statistics show sizeable differences between the central tendency measures of the five ETR definitions as well as sizeable differences in the parametric and nonparametric correlation coefficients of the five definitions (Omer, Molloy and Ziebart, 1991). Additional analyses show that a large percentage of firms move more than two decile ranks when alternative ETR measures are utilized (Omer, Molloy and Ziebart, 1991). Apart from noting that researchers should compare the outcome of their analyses applying different ETR definitions (p. 71, Omer, Molloy and Ziebart, 1991), their study does not pinpoint any particular ETR definitions as being of better quality. Also note that, apart from the operating cash flow denominator ETR measure, the authors only use general format (1) in their ETR definitions.

This is in contrast to Plesko (1999) who uses actual corporate income tax return data to calculate two ETR definitions. The first measure is defined as tax for credits divided by taxable income before net operating losses and special deductions, where the second definition uses tax after credits divided by income subject to tax (Plesko, 1999). The general format Plesko uses is:

$$
\mathrm{ETR}=\mathrm{TP} / \mathrm{TI}
$$

where: $\mathrm{TP}=$ actual corporate tax to be paid (either before or after tax credits)

$\mathrm{TI}=$ taxable income

The empirical data for these two tax return based definitions is compared with the ETR definitions as described by Omer, Molloy and Ziebart (1991). Results from the statistical tests show that the means of the tax return ETR definitions differ in a statistically significant manner from the means of the financial statement data (Plesko, 1999). Based on these results, Plesko (1999) argues against using financial statement data to measure ETRs, proclaiming them to 'to provide little insight about annual corporate tax burdens' (p. 1, Plesko, 1999).

Shevlin (1999) critiques Plesko (1999) for making the assumption that researchers are interested in estimating the statutory tax burden ('tax payable as percentage of taxable income') (Shevlin, 
1999). According to Shevlin researchers are more interested in a more general concept of corporate tax burden ('tax payable as percentage of book income'). Shevlin also critiques Plesko for using a single period measure not taking into account carryback and carryforward rules.

Furthermore, Plesko's approach (1999) is not available to most researchers as he uses proprietary IRS data. However, the main objection against Plesko's ETR definition is that he does not answer the information needs of most tax researchers as stated by Shevlin (1999). Those researchers are mostly interested in gaining knowledge about the amount of tax preferences available to companies and cross-sectional differences in those tax preferences (Callihan, 1994). Plesko's data reveal that taxable income and financial accounting income differ significantly, thus indicating that tax preferences are substantial. This provides however no information on the relative amount of tax preferences available to those companies as Plesko's (1999) ETR measures are calculated using data net of tax preferences.

The next section addresses these shortcomings of Plesko's research and in doing so develops an ETR measure to capture the relative tax preferences attributable to firms, fulfilling Shevlin's (1999) general concept of corporate tax burden. 


\section{ETR MEASURES}

\subsection{Introduction}

This chapter investigates which different ETR measures have and can be used in an empirical setting. This is however, dependent on the measurement goal(s) of the ETR definition being used. Therefore, first the goals of ETR measurement are described, after which the possible alternatives are discussed paying attention to their flaws and in doing so providing information on the validity of ETR measures.

\subsection{ETR measurement goal(s)}

The reasons why researchers would like to know the level of ETR, can be classified in three main ss (Callihan, 1994 and Shevlin,1999):

- to measure the impact of taxes on incentives for investment;

- as an indication of corporate tax burden;

- as measurement of corporate tax preferences.

The first issue, the impact of taxes on incentives for investment is addressed by the marginal effective tax rate, that is the tax rate on an additional doller of investment return earned. Callihan (1994) provides information on different marginal effective tax rates.

ETRs can also be used by management to indicate the corporate tax burden to interested parties. As such ETR general definition (1) is a widely used definition in financial statements and indeed serves as an indication of the relative corporate tax burden. A flaw of the ETR definition used is that the tax expense measure used in the definition is an estimate of the tax liability and therefore has the inherent shortcomings of estimates, i.e. they do not always conform to the actual amounts. To accurately measure the corporate tax preferences (the third group) not estimates should be used but actual data as these provide, per definition, a better indicator of the corporate tax preferences. 
In doing so, this paper will therefore only address the third ETR measurement goal, that is the measurement of corporate tax preferences.

\subsection{ETR measures}

The goal of this paragraph is to list the main ETR measures available and describe some of their major shortcomings. The implicit assumption is that the researcher utilizing one or more of these ETR measures is mostly interested in the measurement of corporate tax preferences. Before starting out with the listing of the ETR measures, it is useful to describe the relationship between financial accounting income and taxable income. As described in the federal tax code and as shown in form 1120 of the Internal Revenue Service ('U.S. Corporation Income Tax Return'), taxable income is calculated as follows:

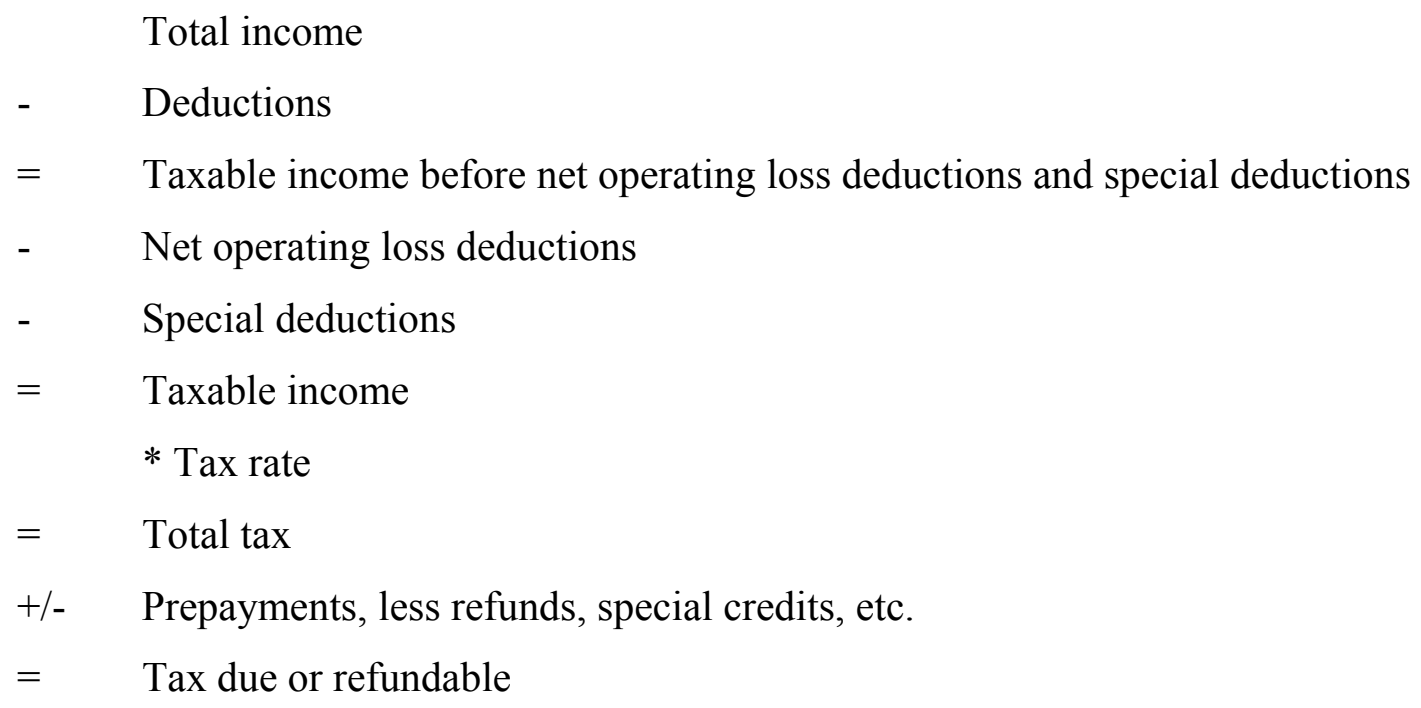

Only looking at the differences between the financial accounting and tax accounting calculation of income and abstracting, for this moment, of net operating loss deductions, special deductions and prepayments, refunds and the like, for a company with only domestic operations this comes down to:

Financial accounting income before taxes

- $\quad$ Tax preferences 
$=\quad$ Taxable income

* Tax rate

$=$ Tax due

In the case of negative taxable income, the tax due will be a net operating loss, that can be offset against prior or future profits. Deriving from this relationship a mathematical formula for firm i in year $\mathrm{t}$ :

$$
\begin{array}{ll}
\mathrm{PTI}_{\mathrm{ti}}-\operatorname{Pref}_{\mathrm{ti}}=\mathrm{TI}_{\mathrm{ti}} & \text { and } \\
\mathrm{TI}_{\mathrm{ti}} * \mathrm{STR}_{\mathrm{ti}}=\mathrm{TP}_{\mathrm{ti}} & \text { or } \\
\operatorname{Pref}_{\mathrm{ti}}=\mathrm{PTI}_{\mathrm{ti}}-\mathrm{TI}_{\mathrm{ti}} &
\end{array}
$$

where:

Pref $=$ tax preferences;

STR = statutory tax rate

Recalling from Callihan (1994), one of the general ETR formats used is:

$$
\mathrm{ETR}_{\mathrm{ti}}=\mathrm{TE}_{\mathrm{ti}} / \mathrm{PTI}_{\mathrm{ti}}
$$

Either in- or excluding deferred taxes in the tax expense nominator, this ETR measure has several possible shortcomings. Regarding deferred taxes, these include:

- deferred taxes are not always reversed, in such cases ETR is overstated (Omer, Molloy and Ziebart, 1991);

- the time value of deferred taxes is not taken into account, thereby possibly overstating ETR;

Due to these shortcomings, deferred taxes are often excluded from the nominator (Callihan, 1994). But even (1) excluding deferred taxes, has several possible drawbacks:

- the tax expense is an estimate of the actual tax burden;

- calculation errors may have been made in the calculation of the tax expense or income estimation; 
- some or all of the tax preferences may have been erroneously in- or excluded from the ETR;

- certain not-codified tax preferences (like tax rulings) might have a lowering effect on the actual tax burden that is not included in the ETR;

- 'dirty surplus' accounting if present, will either over- or understate corporate tax burden as expressed by ETR;

- companies have incentives to show reasonable tax burdens (i.e. ETRs) as reporting low tax burdens might provoke actions by the tax authorities.

As a result of one or more these possible drawbacks, (1) might not be the best available estimate of the actual tax burden of companies. To overcome these disadvantages, Plesko (1999) uses another general format with two ETR definitions, only differing in the ex- or inclusion of net operating loss deductions and special deductions. Plesko's ETR format for firm i in year 1992 is:

$$
\mathrm{ETR}_{\mathrm{i}}=\mathrm{TP}_{\mathrm{i}} / \mathrm{TI}_{\mathrm{i}}
$$

In a theoretical setting, (2) as can be seen from (B) is equal to the statutory tax rate. Plesko's (1999) empirical results reveal a mean of $31.6 \%$ for (2) including net operating loss deductions and special deductions for the year 1992. This is close to the top statutory tax rate of $34 \%$, indicating support for (B).

As stated by Shevlin (1999) Plesko's ETR definition does not fulfill the goal of measuring corporate tax preferences, it actually tries to calculate an estimate of the statutory tax rate as indicated by (B). This is caused by the fact that actual taxes paid are directly calculated from taxable income. As stated on form 1120 of the Internal Revenue Service, taxes due is calculated as the applicable statutory tax rate times taxable income, taking into account prepaid taxes and the like. Therefore, this ETR measure does not seem valid for measurement of corporate tax preferences.

A third general format using cash flows has been used by Omer, Molloy and Ziebart (1991) and Collins \& Shackelford (1995) and is defined for firm $\mathrm{i}$ in year $\mathrm{t}$ as: 


$$
\mathrm{ETR}_{\mathrm{ti}}=\mathrm{TE}_{\mathrm{ti}} / \mathrm{OPCF}_{\mathrm{ti}}
$$

where:

$\mathrm{OPCF}=$ operating cash flow

An alternative full cash-flow ETR (in line with Plesko's (1999) reasoning measure, but then with regard to cash flows) for firm $\mathrm{i}$ in year $\mathrm{t}$ would be:

$$
\mathrm{ETR}_{\mathrm{ti}}=\mathrm{TP}_{\mathrm{ti}} / \mathrm{OPCF}_{\mathrm{ti}}
$$

Major problems with both (3) and (4) are:

- cash flow likely relate to different periods then accrual accounting figures;

- (even over time) operational cash flow does not have to be equal to income before taxes, as both are calculated on a different basis;

- actual taxes paid and operating cash flow likely do not relate to the same period, taxes are usually paid after the cash flow related to these taxes has been generated;

In addressing the possible shortcomings of the tax expense estimation used, a further alternative would be to take the actual tax burden and relate this to financial accounting before taxes. This results for firm $i$ in year $t$ in:

$$
\mathrm{ETR}_{\mathrm{ti}}=\mathrm{TP}_{\mathrm{ti}} / \mathrm{PTI}_{\mathrm{ti}}
$$

The major problem in the application of this ETR measure is that nominator and denominator relate to different time periods, which also holds true for (3) and (4). In general, this might partially be resolved by using lagged variables. Furthermore, it only addresses current tax burdens, comparable to a (1) format ETR measure excluding deferred taxes. As the goal of this paper is to address the quality of the presented ETR measures, the next chapter sets out to use empirical tests looking into the differences between the various ETR measure and which ETR measure(s) statistically differ from each other and might be preferable. In doing so, first a number of hypotheses are formulated.

\subsection{Hypotheses}


To the extent that any of the five general format ETR measures is qualitatively better than any of the other measures, this implicates that those measures are different in a statistically significant sense. Thus, if one of the ETR measures is statistically significant different from any of the other measures this reveals this ETR measure contains different information. From this hypothesis I in the alternative form follows:

I To the extent different ETR measures contain different information, they will differ in a statistically significant degree.

Furthermore, to the extent that companies receive tax preferences (lowering their taxable income) and try to represent a 'fair' managed tax burden to the outside world, ETR measures including a tax burden estimate ('tax expense') should be higher than their counterparts using actual tax burdens ('tax paid'). That is, (1) would be higher than (5) and (3) would be higher than (4). Stated in the alternative form in hypothesis II:

II ETR measures based on estimated tax burden ('tax expense') are higher than their counterparts using actual tax burden ('tax paid').

If ETR measures differ significantly from each other, this indicates they express different information. To the extent these differences are present, quality differences are also present as the various differing ETR measures do not capture the same information content and are thus not able to answer the question to the amount of corporate tax preferences provided to the same degree. The question is then which differing ETR measure(s) best fulfill(s) the research goal of investigating corporate tax preferences. If hypothesis II holds then the estimated tax burden will be a less good indicator of the real ETR of companies than the actual tax burden measures, that is (2), (4) and (5) would be better indicators than (1) and (3) of ETR. If hypothesis II does not hold, no presumption can be made regarding the quality of the various ETR measures. Only that, to the extent hypothesis I holds, the ETR measures do not represent the same information.

If hypothesis I and II would hold, then measures (2), (4) and (5) would be better indicators of a company's ETR. In doing so, (2) would estimate the statutory tax rate and give an indication of 
codified and non-codified tax preferences affecting the tax due but not (to the same extent) taxable income as these would let (2) deviate from the applicable statutory tax rate(s).

In this situation, (4) would provide an indication of the cash flow tax burden. That is, which part of the cash flow from operations is taken up by cash flows for tax payments? Being a relevant indicator for certain corporate activities, such as cash planning, it might not be a relevant indicator of the corporate tax burden as accrual and cash flow data do not necessarily express the same information (

(5) expresses the actual tax cash flow to financial accounting income before taxes. Taking into account time differences between the nominator and denominator, if hypothesis I and II hold then this measure would provide an indication of corporate tax preferences. 


\section{EMPIRICAL SETTING}

\subsection{Data}

To control for possibly deviating foreign tax rates applying to corporate income, only domestic US companies are included with only domestic activities. As the various ETR measures are ratios, negative nominators and denominators are excluded from the sample as these lead to ETR ratios that are difficult to express. Industries having specific corporate income tax provisions are excluded from the sample. $\stackrel{-\rho}{\underline{\underline{P}}}$ e industries include ...

Considering timing differences between nominator and denominator the following adjustments are made:

- Only companies with a fiscal year-end equal to financial accounting year-end being $12 / 31$ of the year are included;

- A data period of 10 years is used (1987-1997), both pooled and yearly data are used in the analysis;

- Lagged data are used where this is applicable (commented upon in chapter 5).

\subsection{Empirical tests}

Firstly, descriptive data are used to characterize the data. To test hypothesis I, two-tailed independent samples T-tests are used to test for differences in the means. For hypothesis II, onetailed independent samples T-tests are used to test for unidirectional differences in means. Additional analyses are run to test for differences in the medians as well as testing for nonparametric differences in the means. 
